\title{
DAIRY COWS WELFARE QUALITY IN LOOSE VS TIE HOUSING SYSTEM
}

\author{
D. Ostojić-Andrić ${ }^{1}$, S. Hristov ${ }^{2}$, Ž. Novaković ${ }^{1}$, V. Pantelić ${ }^{1}$, M. M. \\ Petrović $^{1}$, Z. Zlatanović ${ }^{3}$, D. Nikšić ${ }^{1}$
}

${ }^{1}$ Institute for Animal Husbandry, Autoput 16, P. Box 23, 11080, Belgrade-Zemun, Republic of Serbia

${ }^{2}$ Faculty of Agriculture, Nemanjina 6, 11080, Belgrade-Zemun, Republic of Serbia

${ }^{3}$ Higher Agricultural-food processing school, Ćirila i Metodija 1, Prokuplje, Republic of Serbia

Corresponding author: andricdusica.iah@gmail.com

Original scientific paper

\begin{abstract}
The subject of this research was to determine the effect of the housing system on quality of welfare of dairy cattle in Serbia. Study was realized on six farms, capacity of 30 to 900 cows, with loose and tie housing system. Assessment of the welfare quality parameters was done by using the Welfare Quality ${ }^{\circledR}$ Assessment Protocol for Cattle, 2009. Results of the research show that the welfare quality of dairy animals is under the significant effect of housing system, and that loose system has the advantage when it comes to comfort around resting, easy of movements and health condition of cows. Share of not lame cows $(81 \%)$ and cows with no lesion $(86 \%)$ was significantly higher $(\mathrm{p}<0.01)$ in loose system. Indicator values: duration of lying down movements $(6.53 \mathrm{sec})$, lying down movements with collisions $(18.7 \%)$ and lying outside lying area $(28.4 \%)$ in tie system were significantly higher $(\mathrm{p}<0.01)$ compared to loose system indicating the inadequacy of the housing and lack of comfort. Analysis of indicators associated with cow hygiene (dirty legs and udder) and diseases (dystocia) points to significant gaps in management in both housing systems which represent significant threat to cow welfare quality.
\end{abstract}

Key words: welfare, quality, dairy cows, housing system

\section{Introduction}

Defining, introduction, analysis of the relevance and development of standards of animal welfare on cattle farms have become very important topics in late 20th and early 21 st century. In the last decade, many developed European countries where breeding programs used to be directed and focused on increase of milk production, faced significant problems in the field of animal health and reproduction of dairy cows. Endemic disease, such as lameness and mastitis, as well as different metabolic disorders, infertility and shorter life time, are some of 
the consequences of disturbed welfare on dairy farms (FAWC, 2009). Therefore, in these countries programs of monitoring and analysis of the welfare conditions were introduced, and on basis of these activities periodical reports and recommendations for its improvement are issued. Also, with the development of awareness of consumers on importance of animal welfare associated with quality of food stuffs, it becomes major part of the general concept of food quality (Blokhuis, 2008).

Welfare of dairy cows is defined as degree of their adjustment to conditions which ensure quality living in regard to nutrition and water access, housing facilities, physical, psychic and thermal comfort, safety, expression of main forms of behaviour, social contacts with animals of the same species, absence of unpleasant emotional and physical experiences such as pain, suffering, fear, stress, disease and injuries. To define and use stated indicators in practice, the following studies are of special importance: Bartussek et al. (2000), Bracke et al. (2001) as well as acquired knowledge within the project focused on the welfare quality of the Sixth Framework Program of EU (The Welfare Quality project $\mathbb{\circledR}-a$ ), presented in the study of Blokhuis (2008).

According to several authors (Leaver, 1999; Weary et al., 2000; Fragonesi et al., 2001; Hristov et al., 2006), housing system is a factor that strongly affects the welfare quality of dairy cows, especially in regard to health condition and expression of behaviour. In Serbia, like in most countries, tie system is predominant, since it enables individual treatment of every animal, but at the same time is strong contrast to natural habitat of cattle. Loose system is increasingly introduced in modern cattle breeding, because the freedom to move and separation of function (feeding, watering, lying and milking ) have positive impact on general health status, condition of the animal, duration of exploitation and production performance. Automatisation of work processes in loose system of housing enabled the reduction of human labour to 40 hours per cow annually. Advantages of the loose system are also easier providing of adequate micro-climate and zoo-hygiene conditions. The most known/popular and wide spread way to house a cow in a loose system in European Union are "laying boxes" as well as increasingly stalls/stables with sloping floor. In our country, housing of cows in stables with deep litter is predominant. This is very inexpensive and simple way to house cows characterized with use of significant quantities of litter/bedding (8-10 kg per cow daily) and with adequate application of manure removal, animals are provided with comfort resulting in satisfactory health condition.

It is well known the health is an important component of dairy cow welfare. The incidence and duration of an illness considerable affects the health of the animal (Webster, 2005; Vučinić, 2006). In the study of the effect of housing system on cow health and welfare, Regula et al. (2004) established that housing of cows in loose-stall system or grazing is significantly associated with better health of animals and welfare. In cows housed in tie system with possibility to move occasionally, significantly lower incidence of joint and udder injuries was 
recorded, as well as less veterinary interventions, compared to cows kept constantly in tie system. Results of the studies by Hristov et al. (2005) showed lower incidence of clinical and subclinical mastitis recorded on farms where animals are kept in loose stall system, contrary to farms with tie system.

Objective of this study was to determine the significance of the effect of housing system, i.e. differences between the loose and tie system, on welfare quality of dairy cattle in Serbia. The impact of housing system on some of the welfare factors was analyzed in this study: availability of food, comfort, freedom of movement, absences of injuries and diseases. Specificity of the study is that for the first time in Serbia, the Welfare Quality ${ }^{\circledR}$ Assessment Protocol for Cattle (2009) has been implemented in Serbia, and that has been implemented since 2008 in 10 European contries.

\section{Materials and Methods}

The assessment of welfare quality on selected farms was done by applying the Welfare Quality ${ }^{\circledR}$ Assessment Protocol for Cattle (2009), using the multidimensional concept of the welfare assessment and includes physical and mental health scored through four principles, twelve criteria and over thirty indicatorsmeasures. Table 1 gives the review of all parameters contained in four main welfare principles.

Focus of this research comprised only several of mentioned parameters $(*)$, chosen based on their association with the housing system on farms. Null hypothesis - that housing system affects the animal welfare, was tested, from the aspect that farms implementing the free loose system are better for welfare quality.

Study included total of 6 farms, three with each housing system - loose and tie. Farms were of various capacities, from 34 to 900 cows. On each farm, sample included a group of minimum 30 cows in lactation according to recommendations of the protocol. Total of 168 Simmental and Holstein-Friesian cows in loose system were included in the sample, and 232 in tie system. Assessment of the welfare quality on selected farms was done during winter season 2010/11. Loose system on farms was organized in form of deep litter with/without free range and grazing. Cows in tie system (Grabner's chain) were kept tied during entire year.

Data collected on the farms was processed using the software program Welfare Quality ${ }^{\circledR}$ scoring system, using specific mathematical operation - Choquet integral, enabling adequate assessment/scoring of each measure, criterion and principle adequately, according to its relevance and relative contribution to overall assessment of welfare on the farm. According to scores, criteria and principles, overall assessment classifies the welfare on farms into four qualitative categories: not classified, acceptable, enhanced and excellent. 
Table 1. The principles and criteria that are the basis for the Welfare Quality ${ }^{\circledR}$ assessment protocols

\begin{tabular}{|c|c|c|}
\hline Welfare Principles & Welfare Criteria & Measures \\
\hline \multirow[b]{2}{*}{ Good feeding } & 1 Absence of prolonged hunger & Body condition score* \\
\hline & 2 Absence of prolonged thirst & $\begin{array}{l}\text { Water provision, cleanliness of } \\
\text { water points, water flow, } \\
\text { functioning of water points }\end{array}$ \\
\hline \multirow[t]{3}{*}{ Good housing } & 3 Comfort around resting & $\begin{array}{l}\text { Time needed to lie-down*,animals } \\
\text { colliding with housing equipment } \\
\text { during lying down*,animals lying } \\
\text { partly or completely outside the } \\
\text { lying area*,cleanliness of } \\
\text { udders/flank/upper legs/lower legs* }\end{array}$ \\
\hline & 4 Thermal comfort & As yet no measure developed \\
\hline & 5 Ease of movement & $\begin{array}{l}\text { Presence of tethering*,access to } \\
\text { outdoor loafing area or pasture* }\end{array}$ \\
\hline \multirow{3}{*}{ Good health } & 6 Absence of injuries & Lameness*,integument alterations* \\
\hline & 7 Absence of disease & $\begin{array}{l}\text { coughing, nasal/ocular/vulvar } \\
\text { discharge*,hampered } \\
\text { respiration*,diarrhoea*,milk } \\
\text { somatic cell count*, } \\
\text { mortality*,dystocia*,downer cows* }\end{array}$ \\
\hline & $\begin{array}{l}8 \text { Absence of pain induced } \\
\text { by management procedures }\end{array}$ & Disbudding/dehorning, tail docking \\
\hline \multirow[t]{4}{*}{ Appropriate behaviour } & 9 Expression of social behaviours & Agonistic behaviours \\
\hline & 10 Expression of other behaviours & Access to pasture \\
\hline & 11 Good human-animal relationship & \\
\hline & 12 Positive emotional state & Qualitative behaviour assessment \\
\hline
\end{tabular}

* parameters considered in the study

The statistical significance of the effect of housing system on welfare quality on studied farms was determined by variance analysis (one-way ANOVA) using Statistica 7 software (StatSoft.Inc, 2004).

\section{Results and Discussion}

Results obtained in the study and presented in Table 2, show that scores for welfare criteria are significantly different $(\mathrm{p}<0.01)$ in loose and ties system. With the exception of criterion -Absence of prolonged hunger, where the indicator - \% very lean cows was poorer in loose system, which is in accordance with results obtained by Regula et al. (2004), all other scored criteria indicate the advantage of loose system over tie system of housing. In regard to criterion -good housing and criterion - comfort around resting, it is noticeable that cows kept in the ties system 
have more trouble and discomfort when laying down, which can be associated with inadequate bedding/litter in stalls and collisions with equipment. Statistically significantly higher $(\mathrm{p}<0.01)$ percentage of lameness was established in cows housed in tie system. According to research by Forkman and Keeling (2009) normal duration of laying down movements is less than 5.20 seconds, whereas in our study, in cows housed in loose system a moderate problem in this criterion $(<6.3 \mathrm{sec})$ was observed, and in cows in tie system significant problem $(>6.3 \mathrm{sec})$. Collision with equipment during laying down movements was within normal values $(<20 \%)$.

Hygiene of dairy cows, in addition to significance associated with the health condition of animals and quality of milk, is also important to animals them selves, according to Broom and Fraser (2007). It is also one of the indicators of the assessment of the comfort around resting on farms. Relaying on the findings and recommendations of Forkman and Keeling (2009) it is evident that the hygiene on studied farms is serious problem. Number of cows with dirty lower legs exceeds by far the value of $50 \%$, especially in the loose system with deep litter/bedding. Study by Regula et al. (2004) also shows greater incidence of dirty lower legs in cows in loose system $(60 \%)$ compared to those in tie system $(40 \%)$. Share of cows with dirty udder should not be over $19 \%$, however on studied farms it was in average $70 \%$, without significance of differences between housing systems.

Absence of diseases in herd doesn't mean the presence of optimal welfare of reared animals. However, the presence of diseases is usually indicator of poor welfare conditions (Webster, 2005; Vučinić, 2006). In this study, statistically highly significant effect $(p<0.01)$ of the housing system on incidence of lameness and integument alterations (hairless patches and lesions) was determined. Lameness is one of the major welfare issues because it causes pain to cows and changes of their normal behaviour. Prevalence of lameness in dairy herds in European countries is in the range from $22 \%$ (Whay et al., 2003) to $45 \%$ (Winckler and Brill, 2004) in tie system, and $1 \%$ to $21 \%$ in loose system (Bielfeldtl et al., 2005; Sogstad et al., 2005). In our study, share of lame cows (moderate and serious collectively) in tie system was approx. $70 \%$, and in loose system around $19 \%$ which are considerably higher values compared to those reported by Regula et al. (2004) of $21 \%$ and $13 \%$, respectively. Causes of integument alterations are of different nature and often lack of balanced food causes poor skin condition and disposition to lesions with secondary effect of poor housing conditions and microclimate. According to Table 2, the percentage of cows with at least one hairless patch and no lesion and of cows with at least one lesion was statistically significantly lower $(\mathrm{p}<0.05)$ in loose system, which is in concordance with results of Regula et al. (2004). 
Table 2. The effect of housing system on welfare quality parameters

\begin{tabular}{|c|c|c|c|c|c|c|}
\hline \multirow[t]{2}{*}{$\begin{array}{c}\text { PRINCIPLES AND MEASURES OF WELFARE } \\
\text { QUALITY }\end{array}$} & \multicolumn{2}{|c|}{$\begin{array}{l}\text { LOOSE } \\
\text { HOUSING } \\
\text { SISTEM }\end{array}$} & \multicolumn{2}{|c|}{$\begin{array}{c}\text { TIED HOUSING } \\
\text { SISTEM }\end{array}$} & \multirow[t]{2}{*}{ t-value } & \multirow[t]{2}{*}{$\mathrm{F}$} \\
\hline & Aver. & td. Dev & Aver. & Std. Dev & & \\
\hline \multicolumn{7}{|l|}{ Principle: Good feeding } \\
\hline Welfare criteria-Absence of prolonged hunger, score & 66.63 & 8.15 & 83.9 & 12.5 & -4.47 & ** \\
\hline o very lean cows & 5.07 & 1.53 & 2.24 & 1.78 & 4.67 & ** \\
\hline \multicolumn{7}{|l|}{ I Principle: Good housing } \\
\hline Welfare criteria-Comfort around resting, score & 39.06 & 8.97 & 18.00 & 7.65 & 6.91 & $* *$ \\
\hline Puration of lying down movements, seconds & 5.63 & 0.13 & 6.53 & 0.45 & -7.46 & ** \\
\hline o lying down movements with collisions & 0.00 & 0.00 & 18.72 & 10.92 & -6.64 & $* *$ \\
\hline o lying outside lying area & 12.27 & 17.96 & 28.36 & 5.01 & -3.34 & $* *$ \\
\hline o dirty lower legs & 97.92 & 3.05 & 88.13 & 9.42 & 3.83 & $* *$ \\
\hline o cows with dirty udder & 77.35 & 16.74 & 67.64 & 12.07 & 1.82 & $\mathrm{~ns}$ \\
\hline o cows with dirty flank and upper legs & 89.30 & 7.93 & 85.19 & 7.14 & 1.49 & $\mathrm{~ns}$ \\
\hline Welfare criteria-Easy of movement, score & 93 & 1.69 & 15.33 & 1.29 & 141.4 & $* *$ \\
\hline \multicolumn{7}{|l|}{ II Principle: Good health } \\
\hline Welfare criteria-Absence of injuries, score & 65.23 & 15.08 & 33.23 & 14.4 & 5.92 & $* *$ \\
\hline o not lame cows & 80.96 & 12.06 & 29.45 & 23.21 & 7.63 & $* *$ \\
\hline o moderately lame cows & 15.23 & 10.28 & 54.23 & 13.49 & -8.91 & $* *$ \\
\hline o severely lame cows & 3.80 & 2.51 & 16.32 & 10.04 & -4.69 & $* *$ \\
\hline o cows with no lesion & 86.12 & 10.56 & 61.86 & 36.17 & 2.49 & $* *$ \\
\hline$V_{0}$ cows with at least one hairless patch and no lesion & 7.24 & 6.15 & 38.20 & 17.05 & -6.62 & * \\
\hline$V_{0}$ cows with at least one lesion & 6.81 & 4.39 & 13.68 & 11.95 & -2.09 & * \\
\hline Welfare criteria-Absence of disease, score & 58.1 & 9.66 & 41.2 & 6.58 & 5.59 & $* *$ \\
\hline requency of coughing per cow per $15 \mathrm{~min}$ & 0.33 & 0.49 & 0.00 & 0.00 & 2.65 & $*$ \\
\hline o cows with nasal discharge & 0.00 & 0.00 & 0.27 & 0.39 & -2.65 & $*$ \\
\hline o cows with ocular discharge & 1.04 & 1.52 & 6.44 & 6.08 & -3.34 & $* *$ \\
\hline $0_{0}$ cows with increased respiratory rate & 0.00 & -- & 0.00 & -- & -- & -- \\
\hline Oo cows with diarrhoea & 1.74 & 2.54 & 3.07 & 2.50 & -1.44 & $\mathrm{~ns}$ \\
\hline o cows with vulvar discharge & 1.18 & 1.06 & 1.80 & 1.33 & -1.41 & ns \\
\hline o mastitis (milk somatic cell count $>400000)$ & 1.47 & 1.20 & 1.40 & 0.22 & 0.21 & $\mathrm{~ns}$ \\
\hline o mortality during the last 12 months & 4.89 & 1.05 & 10.34 & 4.71 & -4.37 & $*$ \\
\hline o dystocia & 15.97 & 18.53 & 4.82 & 2.63 & 2.31 & $*$ \\
\hline o downer cows & 1.20 & 0.91 & 0.42 & 0.61 & 2.76 & $*$ \\
\hline
\end{tabular}

* denominates statistically significant differences at the level of $\mathrm{P}<0.05$; ** at the level of $\mathrm{P}<0.01$; nsat the level of $\mathrm{P}>0.05$ 
Within the criterion Absence of diseases, significant effect of housing system $(p<0.01)$ and advantage of the loose system over tie system were established. This is confirmed by studies of Krohn and Rasmussen (1992), Bendixen et al. (1988a and 1988b) and Hultgren (2002). According to research and recommendations by Forkman and Keeling (2009) the following indicator values (\%) were established: nasal and vulvar discharge, diarrhoea mastitis and downer cows with low incidence and without serious impairment to cow welfare. On the other hand, incidence of dystociae, especially in loose system, is alarming and surely contributes to high mortality rate $(4.89 \%-10.34 \%)$ which according to Forkman and Keeling (2009) should not exceed $2.25-4.5 \%$ in dairy herds.

Final score - overall assessment defines the overall state of welfare quality on farms by analysis and scoring of indicators, parameters, criteria and principles. In this research, all farms with loose system were scored/classified as enhanced, whereas in tie system, only one farm was classified as enhanced, and the remaining two as acceptable.

\section{Conclusion}

Realized research has confirmed that housing system significantly influences comfort around resting and health condition of cows. Cows kept in tie system experience more problems in laying down movements, have higher incidence of collisions with equipment and lower score of health status, which reflects negatively on welfare quality, and can also be cause of drop in productivity. Even though the poor hygiene of cows was established in both systems, somatic cell count in average was over 400.000 only in $1.4 \%$ cases. Welfare quality of studied cows in tie system was considerably disturbed by high incidence of laminitis. Considering what causes have influence on the development of this disease, recommendation is that solve this problem through regular hoof treatment, adequate manure removal, correction of the bedding and laying place and optimal balance of the diet. In addition to above mentioned, importance of regular movement of animals as preventive measure is apparent, so application of modified tie systems which enable movement of animals, during the day or season, free ranges or pasture, is very important. Unexpected high incidence of dystocia recorded in the loose system can be consequence of poor farm management. Therefore, great attention in ensuring welfare quality on dairy farms must be focused on rearing of progeny in regard to adequate feeding, optimal time of breeding and choice of bull sires tested for easy calving, and also ensuring of comfortable and hygienically sound environment to cows, especially during partus. Categorization of farms within the system of housing - overall assessment, indicates that on studied farms the welfare quality was acceptable or enhanced, but 
also that there are possibilities for improvement, especially in mentioned parameters.

\title{
Kvalitet dobrobiti mlečnih krava u slobodnom, odnosno vezanom sistemu
}

\author{
D. Ostojić-Andrić, S. Hristov, Ž. Novaković, V. Pantelić, M. M. Petrović, Z.
} Zlatanović, D. Nikšić

\section{Rezime}

Predmet ovog istraživanja bilo je utvrđivanje uticaja sistema držanja na kvalitet dobrobiti mlečnih krava u Srbiji. Ispitivanje je obavljeno na šest farmi, kapaciteta od 30 do 900 krava, sa slobodnim i vezanim sistemom držanja. Ocena parametara kvaliteta dobrobiti obavljena je korišćenjem Welfare Quality ${ }^{\circledR}$ Assesment Protocol for Cattle, 2009. Rezultati istraživanja pokazuju da se kvalitet dobrobiti mlečnih krava nalazi pod značajnim uticajem sistema držanja kao i da slobodni sistem ima prednost kada su u pitanju udobnost/komfor tokom /ležanja, lakoća kretanja i zdravstveno stanje krava. Udeo krava bez znakova šepavosti $(81 \%)$ i krava bez lezija/povreda $(86 \%)$ bio je signifikantno veći $(\mathrm{p}<0.01)$ u slobodnom sistemu. Vrednosti indikatora: pokreti krave tokom leganja $(6.53 \mathrm{sec})$, pokreti krave tokom leganja gde dolazi do kolizije sa drugim grlima $(18.7 \%)$ i ležanje izvan površina za ležanje (28.4\%) u vezanom sistemu su signifikantno veće $(\mathrm{p}<0.01)$ u odnosu na slobodni i ukazuju na neadekvatnost smeštaja i nedostatak komfora. Analiza indikatora vezanih za higijenu krava (prljave noge i vime) i bolesti (distocia) ukazuje na značajne propuste menadžmenta $\mathrm{u}$ oba sistema držanja, koji ozbiljno ugrožavaju kvalitet dobrobiti krava.

\section{References}

BARTUSSEK H., LEEB C.H., HELD S. (2000): Animal needs index for cattle. Federal Research Institute for Agriculture in Alpine Regions BAL Gumpenstein. BENDIXEN P.H., VILSON B., EKESBO I., ÅSTRAND D.B. (1988a): Disease frequencies in dairy cows in Sweden, VI. Tramped teat. Prev. Vet. Med., 6, 17-25. BENDIXEN P.H., VILSON B., EKESBO I., ÅSTRAND D.B. (1988b): Disease frequencies in dairy cows in Sweden. V. Mastitis. Prev. Vet. Med., 5, 263-274.

BIELFELDT J.C., BADERTSCHER R., TOLLE K.H., KRIETER J. (2005): Risk factors influencing lameness and claw disorders in dairy cows. Livest. Prod. Sci., $95,265-271$. 
BLOKHUIS H.J. (2008): International cooperation in animal welfare: the welfare Quality ${ }^{\circledR}$ project. Acta Veterinaria Scandinavica, 50, Supp 11, S10 http://www.actavetscand.com/content/50/S1/S10.

BRACKE M.B.M., METZ J.H.M., DIJKHUIZEN A.A., SPRUIJT B.M. (2001): Development of a decision support system for assessing farm animal welfare in relation to husbandry systems: strategy and prototype. Journal of Agricultural and Environmental Ethics, 14, 321-337.

BROOM D.M., FRASER F.A. (2007): Domestic animal behaviour and welfare. $4^{\text {th }}$ edition CAB International, Wallingford-Oxfordshire, UK.

FAWC (2009): Opinion on the welfare of the dairy cow. Farm Animal Welfare Council, London, United Kingdom, www.fawc.org.uk.

FORKMAN B., KEELING L. (2009): Assessment of animal welfare measures for dairy cattle, beef bulls and veal calves. Welfare Quality Reports, Cardiff University Sweden, 1-314.

FREGONESI J.A., LEAVER J.D. (2001): Behaviour, performance and health indicators of welfare for dairy cows housed in strawyard or cubicle systems. Livestock Production Science, 68, 205-216.

HULTGREN J. (2002): Foot/leg and udder health in relation to housing changes in Swedish dairy herds, Prev. Vet. Med., 53, 165-187.

HRISTOV S., STANKOVIĆ B., RELIĆ R. (2005): Klinički i subklinički mastitis u krava. Biotehnologija u stočarstvu, 21, 29-39.

HRISTOV S., VUČINIĆ M., RELIĆ R., STANKOVIĆ B. (2006): Uslovi gajenja, dobrobit i ponašanje farmskih životinja. Biotehnologija u stočarstvu, 22, 73-84.

KROHN C.C., RASMUSSEN M.D. (1992): Dairy cows under extreme conditions. Production, reproduction, health and stayability. Nat. Inst. Anim. Sci., Viborg, Denmark, Rep., 709.

LEAVER J.D. (1999): Dairy cattle. In: EWBANK R., KIM-MADSLIEN F., HART C.B. (eds), Management and welfare of farm animals. 4th Edition. The UFAWHandbook. Universities Federation for Animal Welfare, Wheathampstead, UK, 17-47.

REGULA G., DANUSER J., SPYCHER B., WECHSLER B. (2004): Health and welfare of dairy cows in different husbandry systems in Switzerland. Preventive Veterinary Medicine, 66, 247-264.

SOGSTAD Å.M., FJELDAAS T., ØSTERÅS O. (2005): Lameness and claw lesions of the Norwegian Red Dairy Cattle housed in loose stalls in relation to environment, parity and stage of lactation. Acta Vet. Scand., 46, 203-217.

VUČINIĆ M. (2006): Ponašanje, dobrobit i zaštita životinja. Fakultet veterinarske medicine, Beograd.

WEBSTER J. (2005): Animal welfare: limping towards eden. Blackwell Publishing.

WELFARE QUALITY® (2009): Welfare Quality® Assesment Protocol for Cattle. Welfare Quality Consortium, Lelystad, Netherlands, 1-181. 
WELFARE QUALITY ${ }^{\circledR}$ SCORING SYSTEM SOFTWARE. Welfare Quality ${ }^{\circledR}$ Consortium, Lelystad, Netherlands. http://www1.clermont.inra.fr WINCKLER C., BRILL G. (2004): Lameness prevalence and behavioural traits in cubicle housed dairy herds - a field study. In: ZEMLJIC B. (ed.) Proceedings of the investigation of farm records.

WEARY D.M., TASZKUN I. (2000): Hock lesions and loose-stall design. J.Dairy Sci., 83, 697-702.

WHAY H.R., MAIN D.C.J., GREEN L.E., WEBSTER A.J.F. (2003): Assessment of the welfare of dairy cattle using animal-based measurements: direct observations and investigation of farm records. Veterinary Record, 153, 197-202.

Received 30 June 2011; accepted for publication 15 August 2011 